\title{
Brazilian ground beef authentication by multiplex polymerase chain reaction
}

\author{
Andrey Carlos do Sacramento de Oliveira ${ }^{1}$ Silvia Cristina da Silva Pedroso ${ }^{2}$ Diogo José Cardilli ${ }^{3}$ \\ Fábio Pereira Leivas Leite $^{4}$ Gabrielle Virgínia Lopes Ferreira ${ }^{1}$ Andréia Silva da Silva ${ }^{1}$ \\ Talita Bandeira Roos ${ }^{1}$ Carina Martins de Moraes $^{1 *}$ Roberta Sales Sousa $^{1}$ \\ Roseli do Socorro Dias Monteiro 5
}

\footnotetext{
${ }^{1}$ Laboratório de Higiene e Qualidade de Alimentos e Laboratório de Microbiologia, Faculdade de Medicina Veterinária, Programa de Pósgraduação em Saúde Animal na Amazônia, Instituto de Medicina Veterinária, Universidade Federal do Pará (UFPA), Campus Castanhal, BR 316, Km 62, Bairro Saudade, 68740-970, Castanhal, PA, Brasil. E-mail: carinamoraes@ufpa.br. "Corresponding author.

${ }^{2}$ Agência de Defesa Agropecuária do Estado do Amapá, Macapá, AP, Brasil.

${ }^{3}$ Ministério da Agricultura, Pecuária e Abastecimento, Vigilância Agropecuária Internacional (VIGIAGRO), Belém, PA, Brasil.

${ }^{4}$ Laboratório de Bacteriologia, Centro de Desenvolvimento Tecnológico (CDTec), Faculdade de Biotecnologia, Universidade Federal de Pelotas (UFPel), Pelotas, RS, Brasil.

${ }^{5}$ Laboratório de Higiene e Qualidade de Alimentos, Universidade Federal do Pará (UFPA), Castanhal, PA, Brasil.
}

ABSTRACT: The aim of the present study was to assess the efficacy ofmultiplex PCR in detecting the adulterationof commercially available ground beefvia addition and/orsubstitution ofground buffalo meat. Experimentally adulterated ground beefsamples were prepared in triplicate, and dilutions of DNA from Bos taurus and Bubalusbubalis were prepared to determine the detection limit of the method. Concurrently, 91 ground meatsamples sold as "ground beef" were collected from differentstores in northern Brazil andanalyzed bymultiplex PCR. Buffalo DNA was detected in $17.5 \%$ of the collected ground meat samples. Our results showed that multiplex PCR is an efficient method for detectingthe incorporation of groundbuffalo meatatpercentages ranging from 10 to $100 \%$ and the incorporation of beef at percentages ranging from 0.1 to $100 \%$ intoground meat samples.

Key words: species identification, Bos taurus, Bubalusbubalis, DNA, adulteration.

Autenticação de carne moída brasileira através de uma reação em cadeia da polimerase multiplex

RESUMO: O objetivo do presente estudo foi avaliar a eficácia da PCR multiplex na detecção da adulteração por adição e/ou substituição de carne bubalina em carne moída bovina, comercialmente disponível. A fim de determinar o limite de detecção da técnica, carnes moídas bovinas fraudadas intencionalmente foram fabricadas em triplicata e, adicionalmente, concentrações conhecidas de DNA das espécies Bostaurus e Bubalusbubalis foram diluidos. Ao mesmo tempo, 91 amostras de carne moída comercializadas como sendo de origem bovina foram coletadas em diferentes comércios na região Norte do Brasil e a PCR multiplex proposta foi realizada. Os resultados demonstraram que o DNA bubalino foi detectado em 17,5\% das amostras de carne moída coletadas. Concluiu-se que a PCR multiplex é uma técnica eficaz, capaz de detectar a incorporação de carne moída bubalina em percentagens que variaram de 10 a 100\%, e a incorporação de carne bovina em percentagens que variaram de 0,1 a 100\% em amostras de carne moída

Palavras-chave: identificação de espécies, Bos taurus, Bubalus bubalis, DNA, adulteração.

\section{INTRODUCTION}

In Brazil, the Ministry of Agriculture, Livestock and Food Supply, through Normative Instruction (NI) 83/2003, defines ground beef as the meat product resulting from the grinding of muscle mass fromcattle carcasses, followed by cooling or freezing. This NI does not impose any restrictions on the use of buffalo meat; however, the Sales Designation (Denominação de Venda) criterionindicates that the food should belabeled as "ground meat" followed by expressions or designations that characterize the product according to its temperature and the species from which it was obtained (BRASIL, 2003).

In recent years, awareness of food safety and quality has increased, and issues such as the adulteration of meat products have become critical in matters involving personal health, economy and religion (MANE et al., 2012a).Although, food adulteration has been reported by various researchers worldwide (MANE et al., 2012b; KARABASANAVARet al., 2013; MOUSAVI et al., 2015), few scientific studies have investigated the frequency of food adulteration in different Brazilian states. Furthermore, fast methods that 
may be routinely used to detect food adulteration are seldom described.

Several studies have reported suitable methods for detecting adulteration of various food products, including analytical protein methods such as electrophoresis, immuno chemistry, and chromatography methods (EGITO et al., 2006; LACHENMEIER et al., 2003). According to SENTANDREU \& SENTANDREU (2014), such methods have limitations regarding reproducibility and specificity and may generate ambiguous results. The same authors also reported that immunoassays have been widely used to validate meat authenticity, albeit with limitations regarding cross-reactions associated with antibody nonspecificity and protein structural changes. CHENG et al. (2014) stated that DNA-based methods are used more frequently, especially due tothe stability and ubiquity of DNA in tissues. Polymerase chain reaction (PCR) is an efficient method for detecting adulteration, and this method has already been usedto detect adulteration in meat products (DAGUER et al., 2010; OLIVEIRA et al., 2015; KARABASANAVAR et al., 2013; ALI et al., 2015). AMARAL et al. (2015) developed a PCR protocol capable of identifying the presence of six animal species in the same reaction. In tests involving commercial sausages, the authors detected labeling inconsistencies regarding the absence of declared meats. Although, several studies have demonstrated the efficiency of PCR for research regarding the adulteration of meat products (OLIVEIRA et al., 2015; KARABASANAVAR et al., 2013; ALI et al., 2015), few articles have reported on commercially available ground meat samples.

Theaim of this study was to assess the efficacy of multiplex PCR for detecting the adulteration of ground beef sold in northern Brazil via the addition and/or substitution of ground buffalo meat.

\section{MATERIALS AND METHODS}

To test the multiplex PCR, commercially available ground meat samples were obtained from shops in the municipalities of Belém and Santarém (Pará) as well as Macapá (Amapá). Sample numbers were calculated based on the districts in each city and according to data from the Brazilian Institute of Geography and Statistics (Instituto Brasileiro de Geografia e Estatística - IBGE; 2012). Given the lack of data in the literature, sample sizes were calculated considering an estimated adulteration prevalence ranging from 1 to $50 \%$ and determined according to the method proposed by SPIEGEL et al. (2004) and BARBETTA et al. (2004) for a 95\% confidence interval and a 5\% tolerable sampling error.

To determine the detection limit of the method, experimentally adulterated ground beef samples were prepared in triplicate with $0.01 \%, 0.1 \%, 1 \%, 5 \%$, $10 \%, 25 \%, 50 \%, 75 \%, 90 \%, 95 \%, 99 \%, 99.9 \%$, and $99.99 \%$ buffalo meat as previously reported by Oliveira et al. (2015). To ensure the specificity of the assay, meat from Sus scrofa domesticus, Ovis aries, Gallus gallus domesticus and Salmo salar was also added in the same proportions (between $0.01 \%$ and $20 \%$ ). Samples of ground meat exclusively containing a single species were produced for use as control samples (100\%).

After the preparation of all the adulterated meat samples, five samples of each group were isolated, and DNA was extracted in triplicate for a total of 225 samples. In addition, known concentrations of DNA (41ng, 40.99ng, 40.95ng, 40.59ng, 38.95ng, $36.9 \mathrm{ng}, 30.75 \mathrm{ng}, 20.5 \mathrm{ng}, 10.25 \mathrm{ng}, 4.1 \mathrm{ng}, 2.05 \mathrm{ng}$, $0.41 \mathrm{ng}, 0.041 \mathrm{ng}$ and $0.0041 \mathrm{ng}$ ) of the species Bos taurus, Bubalus bubalis, Sus scrofa domesticus, Ovis aries, Gallus gallus domesticus and Salmo salar were diluted and mixed in $1 \mathrm{~mL}$ Eppendorf tubes to ensure the specificity of the assay.

DNA was extracted from samplesusing aWizard Genomic DNA Purification kit (Promega ${ }^{\circledR}$, Madison, USA) according to the manufacturer's instructionswith modifications to the initial lysis step suggested by Oliveira (2015): 20mg proteinase K (Ludwig Biotec $^{\circledR}$, Alvorada, RS, Brazil) was added, and samples were incubated overnight in a water bath (DeLeo ${ }^{\circledR}$, Porto Alegre, RS, Brazil) at $65^{\circ} \mathrm{C}$. DNA samples were separated via electrophoresis (Bio-Rad $^{\circledR}$, California, USA) on a $0.8 \%$ agarose gel (Ludwig Biotec ${ }^{\circledR}$, Alvorada, RS, Brazil) in Trisborate-EDTA (TBE) buffer. The TBE buffer consisted ofTrisbase (Promega ${ }^{\circledR}$, Madison, USA), boric acid (Alphatec $^{\circledR}$, Control Lab, Paraná, Brazil) and $0.5 \%$ EDTA (Ludwig Biotec ${ }^{\circledR}$, Alvorada, RS, Brazil). Following electrophoresis, the gel wasimmersed in $5 \mu \mathrm{g} / \mathrm{mL}$ ethidium bromide (Ludwig Biotec ${ }^{\circledR}$, Alvorada, RS, Brazil) for 30 minutes. Electrophoresis results were analyzed using an ultravioletlight imaging device (Transilluminator MultiDoc-It ${ }^{\mathrm{TM}}$, Ultra-Violet Products Ltd., Cambridge, UK) coupled with Total Lab imaging software (Total Lab TL 100, version 2006, Nonlinear Dynamics Ltd.). A BioTek ${ }^{\circledR}$ Gen5 $^{\mathrm{TM}}$ (Bio Tek Instruments, Inc., Winooski, USA) spectrophotometer was used for DNA quantification and purity assessment.Absorbance were measured at wave lengths of $230 \mathrm{~nm}, 260 \mathrm{~nm}$, and $280 \mathrm{~nm}$, and concentrations were calculated according to the BeerLambertlaw (LAMBERT, 1760; BEER, 1852). 
Table 1 shows the primer sequences, target species, amplicon sizes and average melting temperature (Tm) of the PCR assay. Primers were prepared according to the manufacturer's instructions (Ludwig Biotec ${ }^{\circledR}$, Alvorada, RS, Brazil) and were diluted in TE buffer $\mathrm{pH}$ 8.0to a concentration of $100 \mathrm{pmol} / \mu \mathrm{L}$. The proposed multiplex PCR method was conducted as previously reported by DARWISH et al. (2009), with modifications. The final volume ofeach PCR mix was $25 \mu \mathrm{L}$. Each mixcontained $50 \mathrm{mM}$ $\mathrm{KCl}$ (LudwigBiotec ${ }^{\circledR}$, Alvorada, RS, Brazil), $10 \mathrm{mM}$ Tris- $\mathrm{HCl}$ (Ludwig Biotec ${ }^{\circledR}$, Alvorada, RS, Brazil), $1 \mathrm{X}$ buffer, 10mM dNTP mix (Ludwig Biotec ${ }^{\circledR}$, Alvorada, RS, Brazil), approximately 8.2ng of template DNA, $1 \mathrm{U}$ of Taq DNA Polymerase (Ludwig Biotec ${ }^{\mathbb{R}}$, Alvorada, RS, Brazil) and 10pmol of each primer (LudwigBiotec $^{\circledR}$, Alvorada, RS, Brazil).Ultrapure sterile water was used to make up the volume to $25 \mu \mathrm{L}$. The thermocycler (Applied Biosystems VERITI $^{\circledR}$ 96, California, USA) was programmed for 30 cycleswith denaturation, annealing and extension conditions of $93^{\circ} \mathrm{C}$ for $30 \mathrm{~s}, 56^{\circ} \mathrm{C}$ for $30 \mathrm{~s}$ and $72^{\circ} \mathrm{C}$ for $30 \mathrm{~s}$, respectively. An initial denaturation step was performed at $93^{\circ} \mathrm{C}$ for $3 \mathrm{~min}$, and a final extension step was performedat $72^{\circ} \mathrm{C}$ for $10 \mathrm{~min}$. Resulting amplicons were separated via electrophoresis, and theresults were analyzed usingan ultraviolet light imaging deviceas described above.

Multiplex PCR wasperformed on experimentally adulterated ground meats and on binary DNA mixtures. Then, to verify the influence of the use of three primers simultaneously, PCR was performed onexperimentally adulterated ground meats and on binary DNA mixtures using only the cattle or buffalo reverse primer with the aforementioned forward primers (conventional PCR with the multiplex PCR protocol).

\section{RESULTS}

A total of 91 ground meat samples sold as ground beef were collected from different stores within the target study region (67 samples from
Belém, 12 from Santarém and 12 from Macapá). Both multiplex PCR and conventional PCR effectively detected cattle and buffalo DNA: detection limits were $2.05 \mathrm{ng}$ of buffalo DNA and $0.041 \mathrm{ng}$ of cattle DNA. Both PCR methods identified DNA proportions between 10 and $100 \%$ buffalo meat in the ground beef samples and DNA proportions between 0.1 and $100 \%$ beef in the ground buffalo meat samples.

Figure 1 shows the results obtained from different ground meat samples using multiplex PCR and conventional PCR. We did not detect DNA from Sus scrofa domesticus, Ovis aries, Gallus gallus domesticus or Salmo salar with the buffalo or cattle primers.

Buffalo DNA was detected in $17.5 \%$ of the 91 samples. Approximately 6\% (4/67) of theground meat samples collected from Belém, $42 \%$ $(5 / 12)$ of the samples collected from Santarém and $58 \%(7 / 12)$ of the samples collected from Macapá contained buffalo DNA, indicatinga high frequency of adulteration. Of the adulterated samples, 56.25\% $(9 / 16)$ of the samples were classified as adulteration by substitution (only buffalo DNA was detected in the samples), and $43.75 \%(7 / 16)$ of the samples were classifiedas adulteration by addition (bothcattle and buffalo DNA were detected in the samples).

\section{DISCUSSION}

Buffalo meat is frequently associated with the adulteration of meat products (MANE et al., 2012a). In India, buffalo meat is abundantand has a relatively low market value. As a result, buffalo meat is frequently usedas a substitute for more expensive meats (KARABASANAVAR et al., 2013). Results of the present study showed that a similar situation may be occurring in northern Brazil. According to the IBGE, the eastern Amazonis home to the largest buffalo herd in the country, accounting for approximately $60 \%$ of the Brazilian herd. The state of Pará has the largest herd in Brazil, with $36 \%$ of the Brazilian herd, and Amapá has the second largest herd in Brazil, with approximately $20.1 \%$ of the Brazilian herd (IBGE, 2012). Few well-established

Table 1 - Primers used to amplify sequences specific to buffalo and cattle previously reported by LÓPEZ-CALLEJA et al. (2005).

\begin{tabular}{|c|c|c|c|c|}
\hline Primers & Sequence $\left(5^{\prime}-3^{\prime}\right)$ & Target species & Amplicon Size & $\mathrm{Tm}$ \\
\hline Rev cat & AAATAGGGTTAGATGCACTGAATCCAT & Bos taurus & $346 \mathrm{bp}$ & $55.18^{\circ} \mathrm{C}$ \\
\hline Rev buf & TTCATAATAACTTTCGTGTTGTTGGGTGT & Bubalus bubalis & $220 \mathrm{bp}$ & $55.85^{\circ} \mathrm{C}$ \\
\hline For buf - cat & CTAGAGGAGCCTGTTCTATAATCGATA & - & - & $56.70^{\circ} \mathrm{C}$ \\
\hline
\end{tabular}

Ciência Rural, v.48, n.2, 2018. 


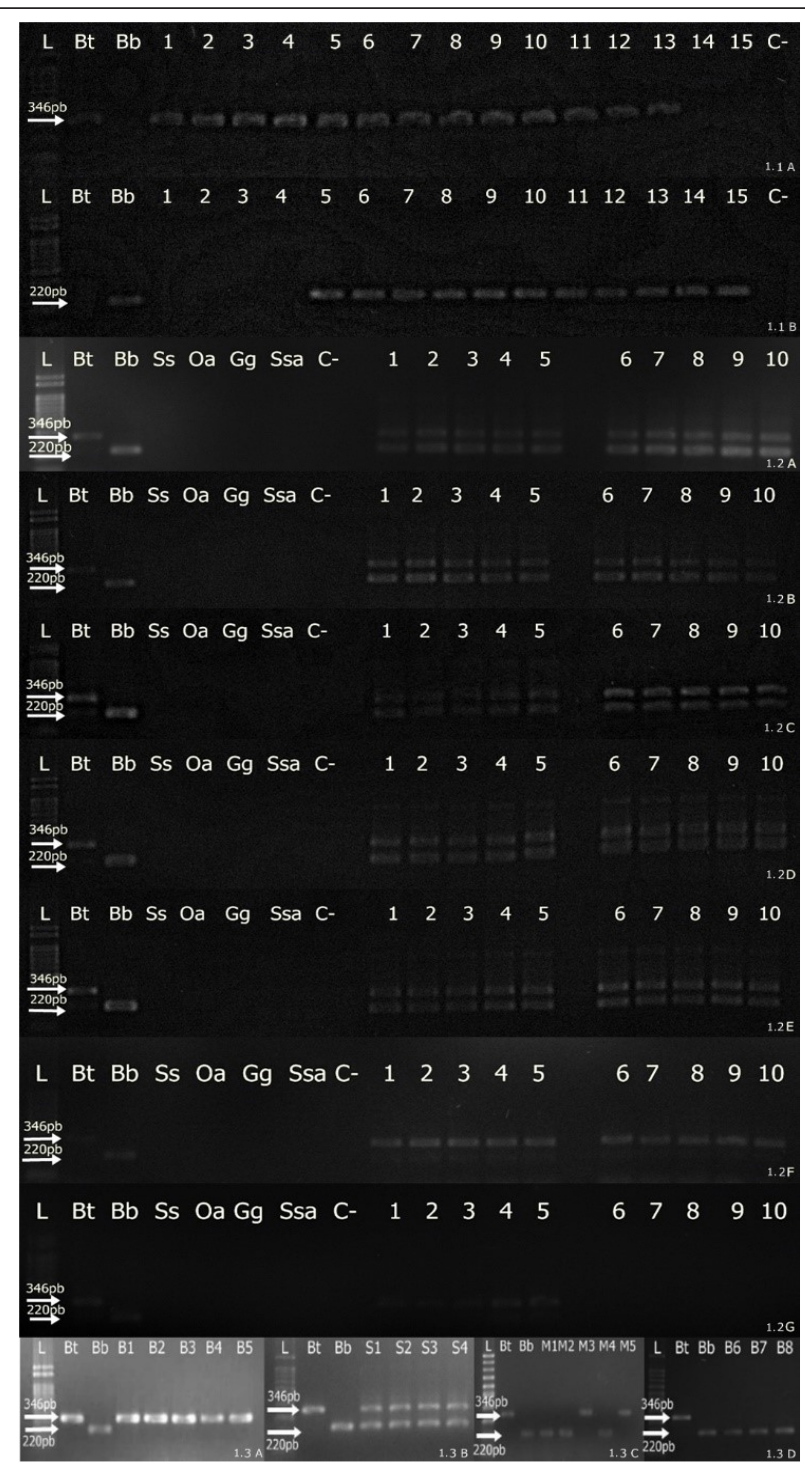

Figure $1-1.5 \%$ agarose gel showing the presence of cattle (346 bp) and buffalo (220 bp) DNA.

1.1 A, B: Conventional PCR (A: reverse primer cattle; B: reverse primer buffalo) of binary mixtures of bovine and buffalo DNA. L: $1 \mathrm{~kb}$ DNA ladder; Bt: cattle control (346 bp); Bb: buffalo control (220 bp); 1: 41ng of cattle DNA/0.00ng of buffalo DNA; 2: 40.99ng of cattle DNA/0.0041ng of buffalo DNA; $3: 40.95 \mathrm{ng}$ of cattle DNA/0.041ng of buffalo DNA; $4: 40.59 \mathrm{ng}$ of cattle DNA/0.41ng of buffalo DNA; 5: $38.95 \mathrm{ng}$ ofc attle DNA/2.05ng of buffalo DNA; 6: 36.9ng of cattle DNA/4.1ng of buffalo DNA; $7: 30.75 \mathrm{ng}$ of cattle DNA/10.25ng of buffalo DNA; $8: 20.5 \mathrm{ng}$ of cattle DNA/20.5ng of buffalo DNA; $9: 10.25 \mathrm{ng}$ of cattle DNA/30.75ng of buffalo DNA; $10: 4.1 \mathrm{ng}$ of cattle DNA/36.9ng of buffalo DNA; $11: 2.05 \mathrm{ng}$ of cattle DNA/38.95ng of buffalo DNA; 12: $0.41 \mathrm{ng}$ of cattle DNA/40.59ng of buffalo DNA; $13: 0.041 \mathrm{ng}$ of cattle DNA/40.95ng of buffalo DNA; 14: 0.0041ng of cattle DNA/40.99ng of buffalo DNA; 15 : 0.00ng of cattle DNA/41ng of buffalo DNA; C-: negative control.

1.2 Multiplex PCR on experimentally adulterated ground meats. L: $1 \mathrm{~kb}$ DNA ladder; Bt: cattle control (346 bp); Bb: buffalo control (220 bp); Ss: pig control; Oa: lamb control; Gg: chicken control; Ssa: fish control; C-: negative control; 1.2A:lanes 1 to 5: 41ng of DNA; lanes 6 to 10: 40.99ng of DNA; 1.2B:lanes 1 to 5: 40.95ng of DNA; lanes 6 to 10: 40.59ng of DNA; 1.2C:lanes 1 to 5: $38.95 \mathrm{ng}$ of DNA; lanes 6 to 10: $36.9 \mathrm{ng}$ of DNA; 1.2D:1 to 5: 30.75ng of DNA; lanes 6 to 10: $20.5 \mathrm{ng}$ of DNA; 1.2E: lanes1 to 5: 10.25ng of DNA; lanes 6 to $10: 4.1 \mathrm{ng}$ of DNA; 1.2F:lanes1 to 5: 2.05ng of DNA; lanes 6 to 10: $0.41 \mathrm{ng}$ of DNA; 1.2G: lanes1 to 5: 0.041ng of DNA; lanes 6 to 10: $0.0041 \mathrm{ng}$ of DNA. 1.3A: Ground meat samples collected in the municipality of Belém. L: $1 \mathrm{~kb}$ DNA ladder; Bt: cattle control (346 bp); Bb: buffalo control (220 bp); lanes B1 to B5: absence of adulteration with cattle DNA (346 bp); 1.3B: Ground meat samples collected in the municipality of Santarém, L: $1 \mathrm{~kb}$ DNA ladder; Bt: cattle control (346 bp); Bb: buffalo control (220 bp); lanes S1 to S4: adulteration by addition of cattle (346 bp) and buffalo (220 bp) DNA; 1.3C: Ground meat samples collected in the municipality of Macapá, L: $1 \mathrm{~kb}$ DNA ladder; Bt: cattle control (346 bp); $\mathrm{Bb}$ : buffalo control (220 bp); M1, M2 and M4: adulteration by substitution with buffalo DNA (220 bp); M3 and M5: absence of adulteration with cattle DNA (346 bp); 1.3D: Ground meat samples collected in the municipality of Belém, L: 1 kb DNA ladder; Bt: cattle control (346 bp); Bb: buffalo control (220 bp); lanes B6 to B8: adulteration by substitution with buffalo DNA (220 bp). 
supply chains existfor the production of buffalo meat in this region, and the price of buffalo meat in such places is approximately $20 \%$ lower than the price of beef (MARQUES et al., 2013). These factors highlighted thefragility of the buffalo supply chain in the states of Amapá and Pará. Because the buffalo supply chain is so fragile, these states were selected as the target study area.Various factors may be related to thehigh incidence of food adulteration detected in the municipalities studied in this research, including an aggravating factor of illegal slaughters. Such slaughters have been reported previously in Brazil (MATHIAS, 2010) and misrepresent the production indices related to beef and buffalo meat consumption.

Several methods of detecting adulteration have been reported, and many researchers have highlighted multiplex PCR as a fast, affordable and simple method for species screening in food (ALI et al., 2015; KARABASANAVAR et al., 2013). These researchers have been able to identify different species within the same reaction, using methods and producing results similar to those reported in this study.

Ground meatstands out among meat products because it is easily prepared at a low costcompared tofresh meat cuts. However, ground meat processing may promote the use of adulteration practices: the grinding process, which reduces the sizes of meat cuts using mechanical forces, significantly changes the appearance of the meat by reducing the sizes of original structures and hinders the identification of the animal species from which the meat is derived (MOTTA et al., 2000). Therefore, larger studies enabling the adulteration of this food product to be detected must be conducted. Results reported here indicated that adulteration by substitution and addition commonly occurs in the geographical regions studied.

Primer specificity and average melting temperature $(\mathrm{Tm})$ are critical in multiplex PCR, as the success of this technique depends on the ability of the primers to selectively anneal with their respective target region sunder a single set of PCR conditions, which includes reaction volume and number of cycles (ALI et al., 2015). The primers designed by LÓPEZ-CALLEJA et al. (2005), who used them to detect cheese adulteration, were used in the present study and were kindly provided by their laboratory. The Tm values of the reverse primers buf and cat and the forward primer buf-cat used in our study were $55.85^{\circ} \mathrm{C}, 55.18^{\circ} \mathrm{C}$ and $56.70^{\circ} \mathrm{C}$, respectively. These values justify the annealing temperature of $56^{\circ} \mathrm{C}$ and 30 cycles of amplification used in the present study. This annealing temperature and cycle number, in concert with the concentrations of the other reagents, provided the optimal conditions for specific binding of all primers within the same PCR. Although, the aforementioned primers have already been used in other studies to detect milk and cheese adulteration (LÓPEZ-CALLEJA et al., 2005; DARWISH et al., 2009), our study demonstrated the use of these primers to detect the adulteration of commercially available meat products. The primers were specific, as they did not detect the species Sus scrofa domesticus, Ovisaries, Gallus gallus domesticus or Salmo salar, suggesting that they may also be used to detect Bos Taurus and Bubalus bubalis DNA in other food products.

Most of the multiplex PCR protocols reported in the literature are based on the hypothesis that each forward primer has a corresponding reverse primer (BAI et al., 2010; ALI et al., 2015). However, the present study usedonly one forward primer and two reverse primers, a condition which could cause competition between primers and affect the sensitivity of thetest (BAI et al., 2010). Thus, to identify possible artifacts related to multiplex PCR, conventional PCR using the forward primer and a single reverse primer were performed. While the forward primer amplified DNA from bothcattle and buffalo, the reverse primer was specific for either cattle or buffalo species. This conventional PCR protocol was tested on experimentally adulterated ground meatsamples and binary DNA mixtures. The results indicated that sensitivity for buffalo DNA was similar when eitherthree or twoprimers were used, confirming the efficiency and optimality of the multiplex PCR method originally proposed by LÓPEZ-CALLEJA et al. (2005) and increasing the credibility of results reported here.

A Quarterly Slaughter Survey (Pesquisa Trimestral do Abate) series has existed since 1997 (IBGE, 2012). However, that initiative did not aim toestimate and count illegal slaughtering in Brazil. Thus, the actual effects that such slaughters have on beef and buffalo consumption are difficult to determine. Reports have indicated that illicit slaughtering accounts for $41 \%$ of the meat supplied to the population in some Brazilian States (BENDER, 1992). This situation weakens the control of adulteration practices, increases the risk of zoonosis transmission and should be analyzed based on the alarming data reported in this reasearch.

\section{CONCLUSION}

The proposed multiplex PCR and conventional PCR proved to be highly sensitive and 
specific, accurately detecting the presence of fraud and adulteration by substitution of ground meat in markets in Belém, Santarém and Macapá, and these adulterated meats were sold in retail outlets without inspection. This situation necessitates the adoption of surveillance measures by official supervisory bodies to protect consumers' rights. The multiplex PCR technique used here is suggested for official use in the future.

\section{ACKNOWLEDGMENTS}

We thank the Office of Pró-reitoria de Pesquisa e Pós-graduação (PROPESP) and the Fundação de Amparo e Desenvolvimento da Pesquisa (FADESP) of the Universidade Federal do Pará (UFPA) for the support provided through the Programa de Apoio à Publicação Qualificada (PAPQ) - Public Notice 01/2016.

\section{REFERENCES}

ALI, M.E. et al. (2015). Multiplex PCR assay for the detection of five meat species forbidden in islamicfoods. Food Chemistry, v.177, p.214-224, 2015. Disponível em: <http://dx.doi. org/10.1016/j.foodchem.2014.12.098>. Acesso em: 30 set. 2015. doi: 10.1016/j.foodchem.2014.12.098.

AMARAL, J.S.; et al. Identification of duck, partridge, pheasant, quail, chicken and turkey meats by species-specific PCR assays to assess the authenticity of traditional game meat Alheira sausages. FoodControl, v.47, p.190-195, 2015. Disponível em: <http:// dx.doi.org/10.1016/j.foodcont.2014.07.009>. Acesso em: 14 dez. 2015. doi: 10.1016/j.foodcont.2014.07.009.

BAI, W.L. et al ..A PCR assay for sex determination of yak (Bos grunniens) meat by amplification of the male-specific SRY gene. FoodControl, v.21, p.726-731, 2010. Disponível em: <http:// dx.doi.org/ 10.1016/j.foodcont.2009.10.016>. Acesso em: 30 set. 2015. doi: 10.1016/j.foodcont.2009.10.016.

BARBETTA, P.A. Estatística para Cursos de Engenharia e Informática. São Paulo: ATLAS, 2004. 376p.

BEER, A. Bestimmung der Absorption des rothen Lichts in farbienFlüssigkeiten. Annalen der Physik, v.152, p.78-82, 1852. Disponível em: <http://dx.doi.org/ 10.1002/andp.18521620505>. Acessoem: 30 set. 2015. doi: 10.1002/andp.18521620505.

BENDER, A.E. Meat and meat products in human nutrition in developing. Food and Agriculture Organization of the United Nations, v.53, p.91, 1992. Disponível em: <http://www.ncbi. nlm.nih.gov/pubmed/1300286>. Acesso em: 30 set. 2015. doi: 10.1016/j.pmid.1300286.

BRASIL. Ministério da Agricultura, Pecuária e do Abastecimento. Instrução Normativa $\mathrm{n}^{\circ} 83$, de 21 de novembro de 2003. Regulamento Técnico de Identidade e Qualidade de Carne Moída de Bovino. Diário Oficial da União, 24 nov. 2003, Seção 1, p.29. Disponível em: <http://extranet.agricultura.gov.br/sislegisconsulta/consultarLegislacao.do?operacao=visualizar\&id $=4317>$. Acessoem: 20 nov. 2014.

CHENG, $\mathrm{X}$ et al. Multiplex real-time PCR for the identification and quantification of DNA from duck, pig and chicken in
Chinese blood curds. Food Research International, v.60, p.30-37, 2014. Disponível em: <http://dx.doi.org/10.1016/j. foodres.2014.01.047>. Acesso em: 14 dez. 2015. doi: 10.1016/j. foodres.2014.01.047.

DAGUER, H.; et al. Perfil eletroforético de lombo suíno adicionado de proteínas não cárneas. Ciência Rural, v.40, n.2, p.434-440, 2010. Disponível em: <http://dx.doi.org/10.1590/ S0103-84782010005000011>. Acesso em: 30 set. 2015. doi: 10.1590/S0103-84782010005000011.

DARWISH, S.F. et al. Evaluation of PCR assay for derection of cow's Milk in water buffalo's milk. World Applied Sciences Journal, v.7, p.461-467, 2009. Disponível em: <http://www. idosi.org/wasj/wasj7(4)/9.pdf>. Acesso em: 30 set.2015. doi: 10.1111/j.1365-2672.2011.05212.x.

EGITO, A.S.; et al. Método eletroforético rápido para detecção da adulteração do leite caprino com leite bovino (2006). Arquivo Brasileiro de Medicina Veterinária e Zootecnia, v.58, p.932939, 2006. Disponível em: <http://dx.doi.org/10.1590/S010209352006000500032>. Acesso em: 30 set. 2015. doi: 10.1590/ S0102-09352006000500032.

INSTITUTO BRASILEIRO DE GEOGRAFIA E ESTATÍSTICAIBGE (2012). Censo Agropecuário 2012. Disponível em: <http:// www.ibge.gov.br/home/estatistica/economia/ppm/2012/default_ pdf.shtm>. Acesso em: 25 nov. 2014.

KARABASANAVAR, N.S.; et al. Development and application of highly specific PCR for detection of chicken (Gallus gallus) meat adulteration. European Food Research and Technology, v.236, n.1, p.129-134, 2013. Disponível em: <http://dx.doi.org/10.1007/ s00217-012-1868-7>. Acesso em: 30 set. 2015. doi: 10.1007/ s00217-012-1868-7.

LACHENMEIER, D.W.; et al. The use of ion chromatography to detect adulteration of vodka and rum. Eur Food Res Technol, v.218, p.105-110, 2003. Disponível em: <http://dx.doi. org/10.1007/s00217-003-0799-8>. Acesso em: 30 set. 2015. doi: $10.1007 / \mathrm{s} 00217-003-0799-8$.

LAMBERT, J.H. Photometria, sive de mensure et gradibusluminis, colorum et umbrae. German: GermanEdition, 1760. v2.

LÓPEZ-CALLEJA, I.; et al. PCR Detectionofcows' milk in waterbuffalomilkand mozzarella cheese. International Dairy Journal, v.15, p.1122-1129, 2005. Disponível em: <http://dx.doi. org/10.1016/j.idairyj.2004.12.003>. Acesso em:30 set. 2015. doi: 10.1016/j.idairyj.2004.12.003.

MANE, B.G. et al. Detection of adulteration of meat and meat products with buffalo meat employing polymerase chain reaction assay. Food Analytical Methods, v.5, n.2, p.296-300, 2012a. Disponível em: <http://dx.doi.org/10.1007/s12161-011-9237-x>. Acesso em: 30 set. 2015. doi: 10.1007/s12161-011-9237-x.

MANE, B.G.; et al ; Beef specific polymerase chain reaction assay for authentication of meat and meat products. FoodChemistry, v.28, p.246-249, 2012b. Disponível em: <http://dx.doi. org/10.1016/j.foodcont.2012.05.031>. Acesso em: 30 set. 2015. doi: $10.1016 /$ j.foodcont.2012.05.031.

MARQUES, C.S.S et al. Clandestine production of beef in Brazil (A clandestinidade na produção de carne bovina no 
Brasil). Revista da Política Agrícola, ano XVII, n. 1, 2008. Disponível em: <https://seer.sede.embrapa.br/index.php/RPA/ article/viewFile/424/375>. Acesso em: 25 jun. 2015.

MOTTA, M.R.A.; et al. Microbiological evaluation of samples of ground beef marketed in supermarkets in the western region of São Paulo (Avaliação microbiológica de amostras de carne moída comercializada em supermercados da região oeste de São Paulo). Revista Higiene Alimentar, São Paulo, v.14, n.78/79, p.59-62, 2000. Disponível em: $<$ http://bases.bireme.br/cgi-bin/wxislind.exe/iah/online/?IsisScript=iah/ h.s\&nextAction=lnk\&base $=$ LILACS\&exprSeluoarch $=278521$ \&index Search=ID\&lang-p $>$. Acesso em: 25 jun. 2015.

MOUSAVI, S.M.; et al. Applicability of species-specific polymerase chain reaction for fraud identification in raw ground meat commercially sold in Iran. Journal of Food Composition and Analysis. v.40, p.47-51, 2015. Disponívelem: <http://dx.doi. org/10.1016/j.jfca.2014.12.009>. Acesso em: 30 set. 2015. doi: 10.1016/j.jfca.2014.12.009.

OLIVEIRA, A. C. S. O.; et al. Avaliação da técnica PCR multiplex para detecção de fraude por adição de carne bubalina em carne moída bovina. Revista do Instituto Adolfo Lutz, v.74 (4), p.371379, 2015. Disponível em: <http://revistas.bvs-vet.org.br/rialutz/ article/view/31940>. Acesso em: 31 out. 2015.

SENTANDREU, M.A. et al. Authenticity of meat products: Tools against fraud.Food Research International, v.60, p.19-29, 2014. Disponível em: <http://dx.doi.org/10.1016/j. foodres.2014.03.030>. Acesso em: 14 dez. 2015. doi: 10.1016/j. foodres.2014.03.030

SPIEGEL, R.A. Probabilidade e estatística. Porto Alegre: Bookman, 2004. 2.ed. 398p. 